\title{
4. MULTICHANNEL SEISMIC REFLECTION SURVEYS OF LEG 60 SITES, DEEP SEA DRILLING PROJECT ${ }^{1,2}$
}

Cary L. Mrozowski, Dennis E. Hayes, and Brian Taylor, Lamont-Doherty Geological Observatory of Columbia University, Palisades, New York, and The Department of Geological Sciences, Columbia University, New York.

\section{INTRODUCTION}

Extensive geophysical and geological survey work was carried out in the Philippine Sea and Mariana Arc regions prior to the DSDP Leg 59 and Leg 60 drilling. This work included the collection of 24 -fold multichannel seismic (MCS) reflection data aboard the R/V Robert D. Conrad of the Lamont-Doherty Geological Observatory. In the following report we present and interpret the MCS sections across the Leg 60 drill sites (Sites 452-461); the MCS data from the Leg 59 sites have been presented by Langseth and Mrozowski (1980).

\section{BACKGROUND}

An east-west trending transect of holes was drilled from the West Philippine Basin to the Pacific plate during Legs 59 and 60 . This transect was designed (1) to test the ages proposed for the West Philippine Basin, the Parece Vela Basin and the Mariana Trough, (2) to compare the petrologies of rocks from these basins, (3) to establish the type and timing of volcanism on the PalauKyushu Ridge, the West Mariana Ridge, and the Mariana Ridge, and (4) to determine the history of subduction and mode of accretion at the Mariana Trench (site reports, this volume; Kroenke, Scott, et al., 1980).

Leg 60 Sites 453 through 456 were drilled in the Mariana Trough (Fig. 1). Site 453 was positioned to date the oldest crust in the Trough; Site 454 and Sites 455 and 456 were drilled to sample, respectively, newly formed crust and crust of an age intermediate to those at Sites 453 and 454 . Site 457 was drilled on the northeast flank of Alamagan Island (Mariana Ridge) in an attempt to recover a section for comparison with the Palau-Kyushu Ridge and West Mariana Ridge sections (Leg 59 Site 448 and 451; Kroenke, Scott, et al., 1980). Sites 460 and 461 were drilled on the inner wall of the Mariana Trench to sample materials from the subduction complex and to examine the style of deformation at these sites. Site 452 was drilled east of the trench axis to establish a Pacific plate reference section. This section was to be used to identify any materials recovered at Sites 460 and 461 which were scraped from subducted Pacific crust. The remaining Leg 60 sites (Sites 458 and $459)$ were drilled within the Mariana fore-arc. The objectives of these sites were to sample the fore-arc base-

\footnotetext{
1 Initial Reports of the Deep Sea Drilling Project, Volume 60.

2 L-DGO Contribution No. 3072.
}

ment and to determine the sedimentary history of the region.

\section{SITE 452}

This site is located on the Pacific plate approximately $75 \mathrm{~km}$ east of the Mariana Trench axis in 5860 meters of water. As at other nearby Pacific plate DSDP sites (e.g., Sites 194 and 195; Heezen, MacGregor, et al., 1973), difficulties in penetrating chert-bearing horizons hampered drilling operations; only 46.5 meters of sediment was penetrated. These sediments consisted of 25 meters of Quaternary pelagic clay above siliceous mudstones and cherts of Cretaceous age (Site 452 report, this volume). MCS profile 1 (Fig. 2) passes slightly north of Site 452. No correlations between the short section drilled and the reflection record can be made. The general acoustic stratigraphy observed in profile 1 , a 0.20 - to 0.25 -second-thick upper transparent layer above a 0.5 to 0.6-second-thick "reverberant" or "opaque" layer, is typical of much of the northwestern Pacific (Ewing et al., 1968; Houtz and Ludwig, 1979). The chert-bearing mudstone recovered at Site $\mathbf{4 5 2}$ must, at least locally, form part of the transparent layer.

Houtz and Ludwig (1979) suggest that the reverberant layer east of the Mariana Trench is composed of stratified calcareous sediment, although near seamounts it may be formed of volcanoclastic deposits. Average compressional wave velocities of $2.0 \pm 0.3 \mathrm{~km} / \mathrm{s}$ (nine computations) for the transparent layer and $3.3 \pm 0.7$ $\mathrm{km} / \mathrm{s}$ (nine computations) for the reverberant layer have been determined from MCS data along the profile. Thicknesses of 200-250 meters and 800-1000 meters, respectively, can be computed for these layers. Immediately below the reverberant layer, interval velocities (determined from refraction data) are typical of crustal Layer 2 (stations C20-179, C20-182, HIG 24, and HIG 25; Table 1). A possible MOHO refraction observed on the C20-179 sonobuoy record suggests that the intermittent reflection approximately $2.25-2.50$ seconds below the sea floor on profile 1 may be from the crust/mantle interface.

\section{SITE 453}

This site is the westernmost of the four Mariana Trough drill sites and is located in an elongate, northeast-southwest trending sediment pond approximately $20 \mathrm{~km}$ east of the West Mariana Ridge. Drilling at the site penetrated 455.5 meters of unconsolidated to lithified sediments (mainly volcanic muds, silts, and sands 

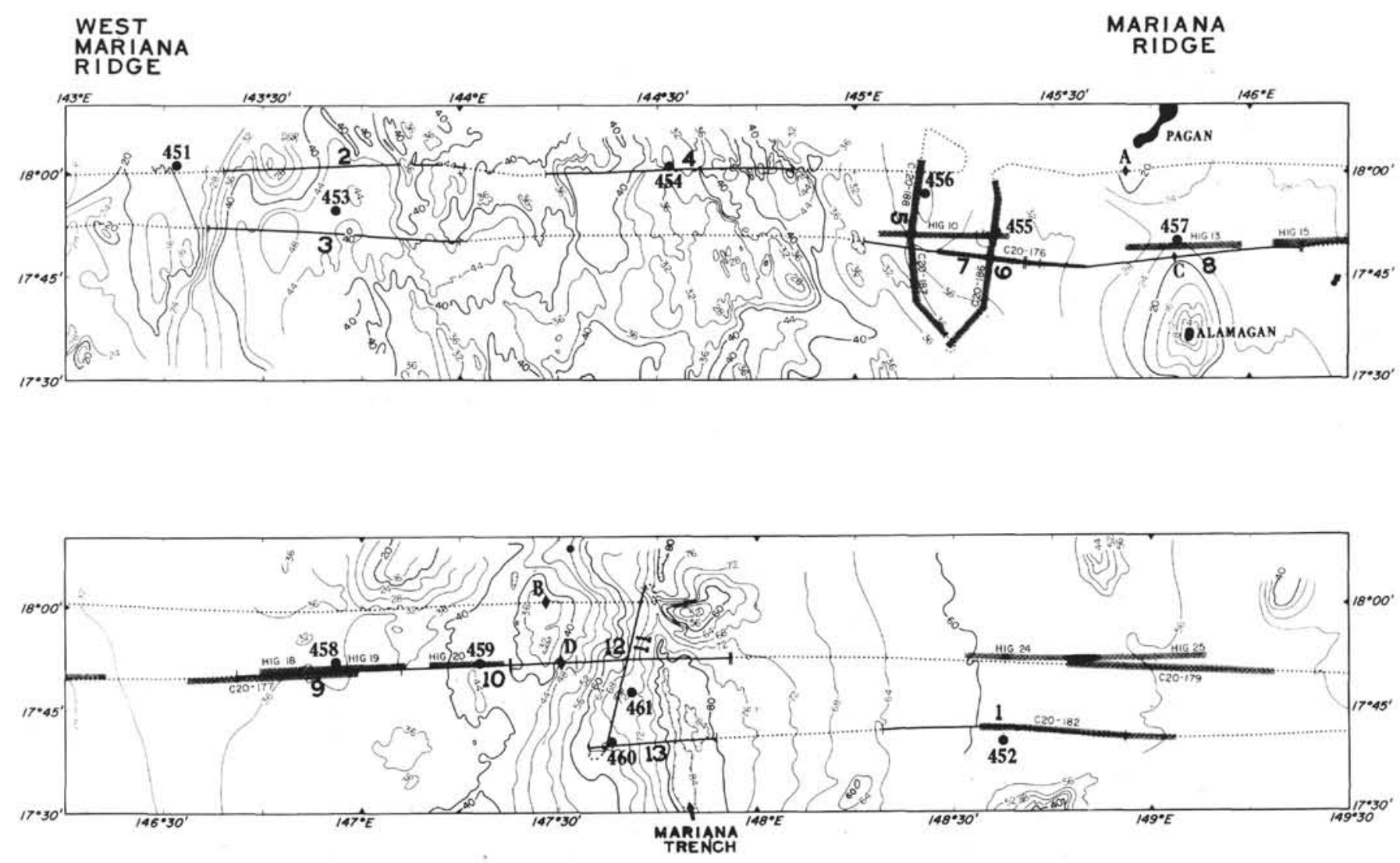

Figure 1. Bathymetric map of the Mariana region simplified from Hussong (this volume) and Langseth and Mrozowski (1980). Contours in hundreds of meters. R/V Conrad 20-06 ship track is shown by the dotted line. MCS profiles 1-13 (Figs. 2-3 and 8-9) are indicated by solid lines; profiles 7 and 8, and 10 and 12 overlap. Sonobuoys (Table 1) are shown by screened bars and DSDP sites by numbered circles. Line drawings of segments $\mathrm{A}-\mathrm{B}$ and $\mathrm{C}-\mathrm{D}$ are shown in Figure 7.

of Pliocene-Pleistocene age) above 85.5 meters of igneous polymict breccia and 35.5 meters of sheared serpentinite-gabbro cataclastites (Site 453 report, this volume).

MCS profiles 2 and 3 (Fig. 3) bracket Site 453 to the north and south, respectively, and clearly show the ridge and pond topography which characterizes the western portion of the Mariana Trough. Since diffractions from the rough, thinly sedimented sea floor obscure most of the profiles, the only well-defined sub-sea-floor reflections are observed in the sediment ponds. It is very difficult to correlate the Site 453 drilling results with reflectors recorded on profiles 2 and 3. The coarse breccias recovered from the bottom of the hole could be highly localized and may not be elsewhere in the pond. Nevertheless, we tentatively correlate the second west-dipping reflector immediately east of the data gap on profile 3 with the top of the breccia unit. Below this reflector an interval velocity of $5.3 \mathrm{~km} / \mathrm{s}$ has been computed from the MCS data; this is in approximate agreement with measured velocities of the breccia samples (Site 453 report, this volume).

\section{SITE 454}

This site was located in a small sediment pond atop the axial high of the Mariana Trough, some $28 \mathrm{~km}$ west of the Mariana Trough spreading center. At this site, 67 meters of Pleistocene vitric muds, ash, and biogenic sediments was cored above about 105 meters of interbedded basalt flows, pillow basalts, and sediments (Site 454 report, this volume).

Profile 4 (Fig. 4) clearly illustrates the roughness of the topography and the sparse sediment cover near Site 454. As at Site 453, diffractions overprint much of the profile, and coherent reflectors are difficult to detect except in the sediment ponds. The west-dipping reflector 0.20 - to 0.25 -seconds sub-sea floor at Site 454 represents the contact between the mud and ash unit and the interbedded basalts and sediment. Detailed velocity analyses by Hegarty et al. (1980) on the westernmost portion of profile 4 indicate that three upper crustal layers may be present (a 1.0-1.5-km-thick $3.04 \pm 0.19-\mathrm{km} / \mathrm{s}$ layer, a $1.5-\mathrm{km}$-thick $3.99 \pm 0.29-\mathrm{km} / \mathrm{s}$ layer, and a $1.4-\mathrm{km}-$ thick $6.10 \pm 0.45-\mathrm{km} / \mathrm{s}$ layer), although reflectors corresponding to these horizons are not apparent on this reflection record.

\section{SITES 455 AND 456}

These sites are located east of the Mariana Trough spreading center (by 54 and $37 \mathrm{~km}$, respectively) and are on the distal portion of a volcanogenic sediment wedge. This wedge thickens toward the Mariana Ridge and covers much of the eastern half of the Trough. At Site 455,22 meters of volcanic muds and ash layers overly- 

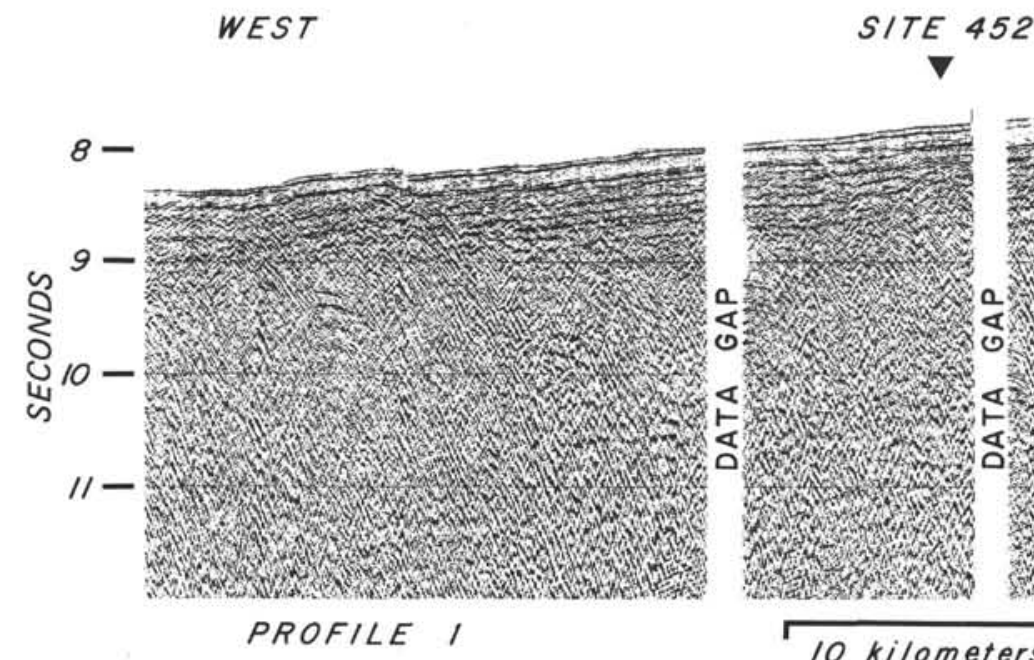

EAST
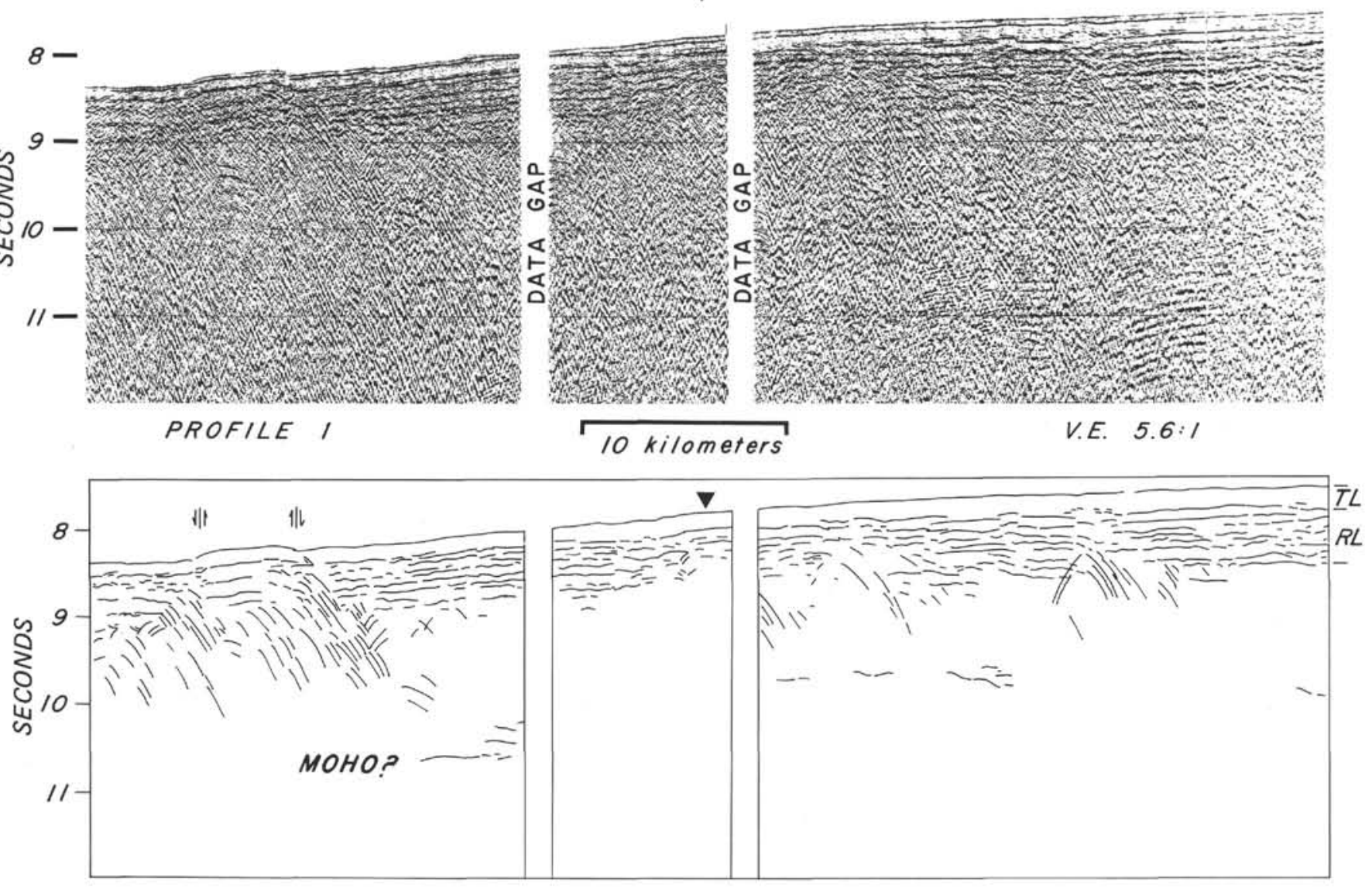

Figure 2. MCS profile 1 record section and line drawing. TL indicates transparent layer. RL indicates reverberant layer. This profile and those in Figures 3-6 and 8-9 have been stacked and deconvolved.

Table 1. Selected refraction data from near the Leg 60 sites.

\begin{tabular}{|c|c|c|c|c|c|c|c|c|c|c|c|c|c|c|c|c|}
\hline \multirow[b]{2}{*}{ Sonobuoy ${ }^{\mathrm{a}}$} & \multirow[b]{2}{*}{ Water } & \multicolumn{6}{|c|}{ Layer Thickness $(\mathrm{km})$} & \multirow[b]{2}{*}{$v_{2}$} & \multirow[b]{2}{*}{$v_{3}$} & \multicolumn{4}{|c|}{ Layer Velocity $(\mathrm{km} / \mathrm{s})$} & \multirow{2}{*}{$\mathrm{v}_{8}$} & \multirow{2}{*}{$\begin{array}{l}\text { Latitude } \\
\text { (N) }\end{array}$} & \multirow{2}{*}{$\begin{array}{l}\text { Longitude } \\
\text { (E) }\end{array}$} \\
\hline & & $h_{2}$ & $h_{3}$ & $h_{4}$ & h5 & $h_{6}$ & h7 & & & $v_{4}$ & $v_{5}$ & $v_{6}$ & $v_{7}$ & & & \\
\hline $\mathrm{C} 20-176$ & 3.61 & 0.65 & 0.97 & & & & & 2.92 & 3.78 & 5.03 & & & & & $17^{\circ} 48.7^{\prime}$ & $145^{\circ} 09.5^{\prime}$ \\
\hline C20-177 & 3.44 & 1.02 & 1.93 & 0.39 & 5.29 & & & $2.00^{\mathrm{b}}$ & 3.97 & 5.10 & 6.20 & 8.42 & & & $17^{\circ} 49.7^{\prime}$ & $146^{\circ} 33.1^{\prime}$ \\
\hline C20-179 & 5.73 & 0.32 & 0.93 & 1.48 & 3.55 & & & 2.69 & 3.90 & 5.30 & 6.94 & 7.65 & & & $17^{\circ} 50.9^{\prime}$ & $148^{\circ} 47.0^{\prime}$ \\
\hline C20-182 & 5.51 & 1.27 & 1.08 & & & & & $3.00^{\mathrm{b}}$ & 5.50 & 6.24 & & & & & $17^{\circ} 40.6^{\circ}$ & $149^{\circ} 03.1^{\prime}$ \\
\hline C20-186 & 3.30 & 0.85 & 0.55 & 1.30 & & & & $2.00^{\mathrm{b}}$ & 3.13 & 3.97 & 5.34 & & & & $17^{\circ} 57^{\prime} 6^{\prime}$ & $145^{\circ} 20.8^{\prime}$ \\
\hline C20-187 & 3.44 & 0.03 & 0.34 & 1.45 & & & & $2.00^{\mathrm{b}}$ & 2.79 & 3.42 & 6.12 & & & & $17^{\circ} 44.7^{\prime}$ & $145^{\circ} 08.7^{\prime}$ \\
\hline C20-188 & 3.63 & 0.86 & 1.71 & & & & & 2.69 & 5.13 & 6.51 & & & & & $17^{\circ} 51.2^{\prime}$ & $145^{\circ} 08.5^{\prime}$ \\
\hline HIG 10 & 3.42 & 0.46 & 1.05 & 2.11 & & & & $2.00^{\mathrm{b}}$ & 3.38 & 5.55 & 6.91 & & & & $17^{\circ} 51.2^{\prime}$ & $145^{\circ} 03.8^{\prime}$ \\
\hline HIG 13 & 2.97 & 1.36 & 0.96 & 1.15 & & & & $2.56^{\mathrm{C}}$ & 3.13 & 4.61 & 6.54 & & & & $17^{\circ} 49.0^{\prime}$ & $145^{\circ} 41.0^{\prime}$ \\
\hline HIG 15 & 2.69 & 0.80 & 1.58 & 1.15 & 1.77 & & & $2.00^{\mathrm{b}}$ & 3.63 & 4.73 & 6.32 & 7.22 & & & $17^{\circ} 49.9^{\prime}$ & $146^{\circ} 03.3^{\prime}$ \\
\hline HIG 18 & 3.43 & 0.40 & 2.93 & & & & & $2.00^{\mathrm{b}}$ & 4.29 & 6.15 & & & & & $17^{\circ} 50.6^{\prime}$ & $146^{\circ} 44.6^{\prime}$ \\
\hline HIG 19 & 3.54 & 0.29 & 1.44 & 1.99 & & & & $2.00^{\mathrm{b}}$ & 4.00 & 4.68 & 6.10 & & & & $17^{\circ} 50.8^{\prime}$ & $146^{\circ} 55.6^{\prime}$ \\
\hline HIG 20 & 3.88 & 0.60 & 1.53 & 1.79 & & & & $2.00^{\mathrm{b}}$ & 4.14 & 5.32 & 6.50 & & & & $17^{\circ} 51.4^{\circ}$ & $147^{\circ} 10.7^{\prime}$ \\
\hline HIG 24 & 6.01 & 0.30 & 1.09 & 0.90 & 2.04 & & & $2.00^{\mathrm{b}}$ & $3.50^{\mathrm{b}}$ & 5.39 & 6.60 & 7.91 & & & $17^{\circ} 52.9^{\prime}$ & $148^{\circ} 31.7^{\prime}$ \\
\hline HIG 25 & 5.77 & 0.15 & 0.49 & 1.13 & 0.92 & 1.20 & 2.90 & $2.00^{\mathrm{b}}$ & $3.06^{\mathrm{C}}$ & 4.11 & 5.89 & 6.54 & 7.38 & 8.20 & $17^{\circ} 52.4^{\prime}$ & $148^{\circ} 48.0^{\prime}$ \\
\hline
\end{tabular}

${ }^{a}$ Sonobuoys with prefix C20 (R/V Conrad Cruise 20, Leg 6) were recorded simultaneously with the MCS data given in this paper and were presented by Hayes et al., 1978. HIG sonobuoys are from LaTraille and Hussong (in press).

b Assumed velocity.

c Average velocity - velocity gradient present rather than discrete layer.

ing 74 meters of dominantly volcanic sand and gravel was penetrated (Site 455 report, this volume). The hole bottomed in vitric mudstone and graded tuff. Hole 456 penetrated 56 meters of upper Pleistocene vitric mud and nannofossil ooze with ash layers, 78 meters of lower Pleistocene semilithified vitric mudstone and nannofos- sil chalk, and 35 meters of aphyric pillow basalts with some interbedded limestone and mudstone (Site 456 report, this volume). The sediments are recrystallized at the basalt contacts, and hydrothermal alteration is evident at the bottom of the hole. A second hole (Hole 456A) was drilled 200 meters from Site 456 to explore 


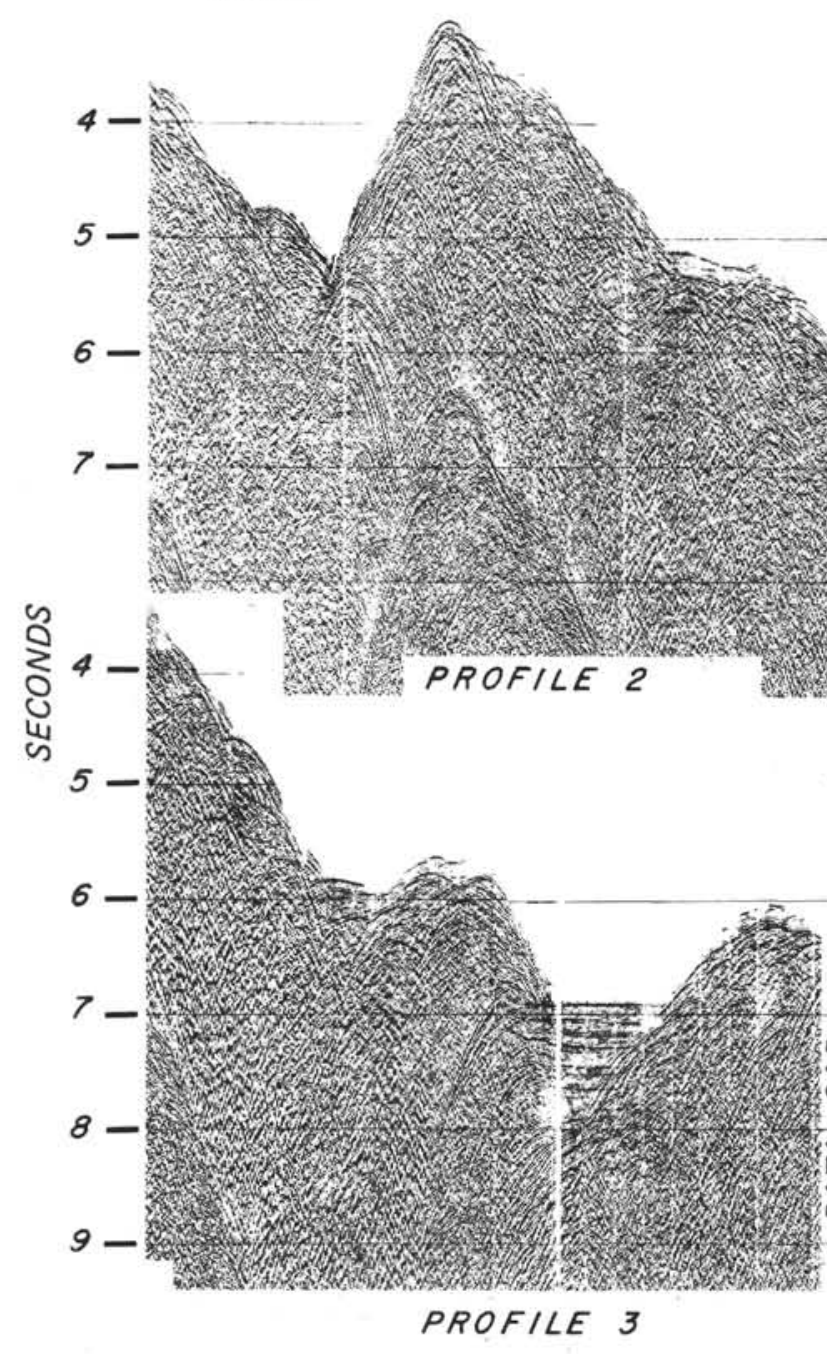

SITE 453


r.

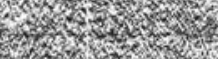

tris

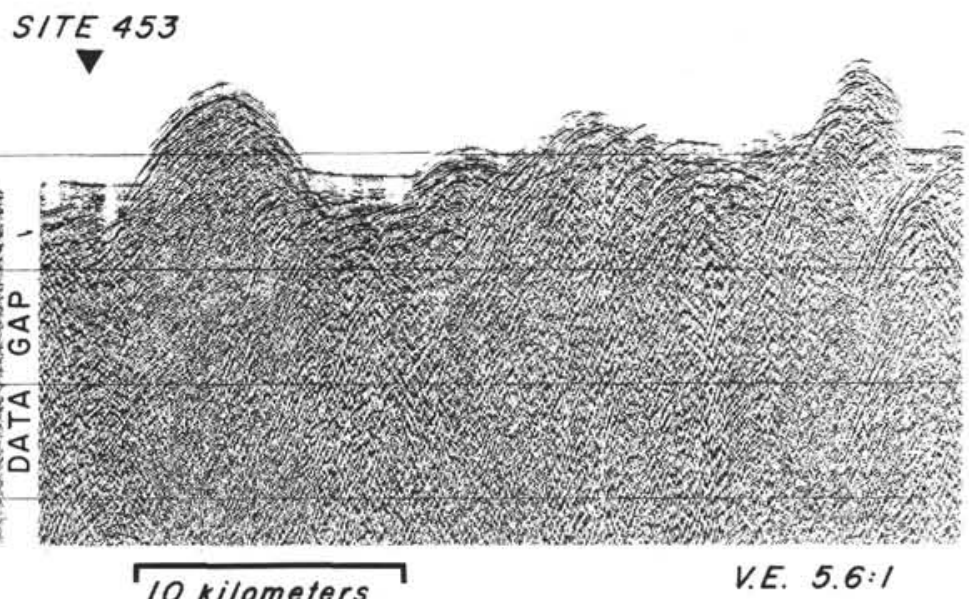

Figure 3. MCS profiles 2 and 3.

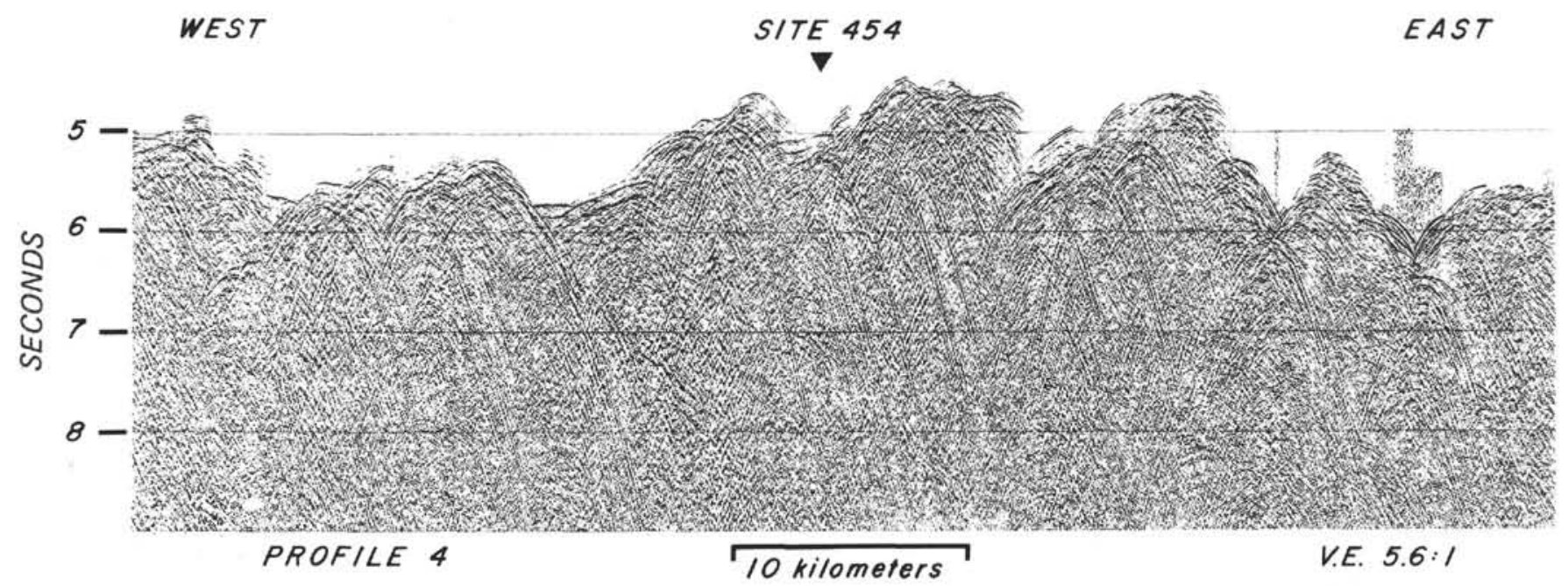

Figure 4. MCS profile 4. 
the lateral extent of the alteration. The sections at both holes are similar, although the mudstone-chalk unit is thinner at Hole 456A.

MCS profiles 5, 6, and 7 (Fig. 5a and b) pass near Sites 455 and 456 . A strongly reflective unit, observed on these profiles immediately below an upper, transparent layer, has an interval velocity generally ranging from $3.0-4.0 \mathrm{~km} / \mathrm{s}$ (computed from MCS data, and refraction stations C20-176, C20-186, C20-187, C20-188, and HIG 10; Table 1) and may be correlated with the interbedded sediment and basalt unit cored at Site 456 . Similar velocities have been recorded in much of the Mariana Trough (LaTraille and Hussong, in press; Kan et al., 1978; Hayes et al., 1978), and suggest a regional occurrence of this unit. Velocity data from along the profiles indicate more "normal" Layer 2 velocities below this unit. Profile 6 crosses over Site 455, but no clear relationship is evident between the acoustical stratigraphy and the short section drilled at the site. The deep subhorizontal reflectors observed at 6.5 to 7.0 seconds on profile 6 may correspond to the top of a $6.91-\mathrm{km} / \mathrm{s}$ layer recorded at station HIG 10 (Table 1).

\section{SITE 457}

This site is located on the northeast flank of Alamagan, a volcanic island on the Mariana Ridge (Fig. 1). Drilling was unsuccessful; the site had to be abandoned owing to hole instability after penetrating only 51.5 meters of coarse, late Pleistocene volcanic sands (Site 457 report, this volume).

Profile 8 (Fig. 6) passes high up the flank of Alamagan Island about $8 \mathrm{~km}$ south of the drill site. The profile reveals little of the structure of the Mariana Ridge but clearly shows the thick volcanogenic sediments of the Mariana Trough to the west and the fore-arc basin to the east. In the Trough, an upper sedimentary layer thickens to the east from 0.2 seconds at the western end of the profile to a maximum 1.1 seconds, and is characterized by compressional wave velocities ranging from 1.8 to $2.0 \mathrm{~km} / \mathrm{s}$. MCS velocity data and refraction station HIG 13 (Table 1) record three units below these sediments. The deepest lies below 6 seconds and has a velocity of about $6.5 \mathrm{~km} / \mathrm{s}$. The two middle units have velocities of 2.2 to $2.4 \mathrm{~km} / \mathrm{s}$ (increasing to $3.5 \mathrm{~km} / \mathrm{s}$ as the ridge is approached) and 4.2 to $4.5 \mathrm{~km} / \mathrm{s}$. The above-mentioned velocity increase may be caused by compaction and void filling associated with the increased thickness of the upper sedimentary layer. Interval velocities for the fore-arc sediments range from 1.8 $\mathrm{km} / \mathrm{s}$ to greater than $3.0 \mathrm{~km} / \mathrm{s}$. Velocities of 4.5 to 5.5 $\mathrm{km} / \mathrm{s}$ have been computed for below the west-dipping deep reflectors in the eastern portion of the profile using MCS data and refraction station HIG 15 (Table 1). These velocities probably correspond to an igneous fore-arc basement as discussed in the next two sections.

\section{SITE 458}

This site was the first of two drill sites occupied in the thickly sedimented Mariana fore-arc region and is located approximately $90 \mathrm{~km}$ west of the Mariana Trench axis (Fig. 7). At this site 256.6 meters of sediment was penetrated (Site 458 report, this volume). The sediments can be divided into four units: (1) Pliocene-Pleistocene siliceous-calcareous ooze with vitric ash $(0-28.5$ $\mathrm{m})$, (2) Pliocene-Miocene (?) nannofossil ooze (28.5$95.0 \mathrm{~m})$, (3) Miocene to lower Oligocene nannofossil chalk (95.0-247.0 m), and (4) lower Oligocene siltstone and sandstone $(247.0-256.6 \mathrm{~m})$. Two major igneous units were cored below the sediments: an upper unit of aphyric, two-pyroxene basalts with unusual high- $\mathrm{MgO}$ andesites (256.6-379.0 m) and a lower unit of predominantly augite-plagioclase basalt with minor high- $\mathrm{MgO}$ andesites. Total penetration at the site was 465.5 meters.

Profile 9 (Fig. $8 \mathrm{a}$ and b) is located approximately 2 $\mathrm{km}$ south of Site 458 . The sediments in the profile are highly faulted and can be seen to be underlain by an eastward-shoaling basement characterized by overlapping diffraction hyperbolas (see also Fig. 7). Although no good correlation can be made between the sedimentary horizons encountered while drilling at Site 458 and the acoustical stratigraphy displayed in profile 9 , it is likely that the base of the stratified, relatively transparent, upper layer corresponds to the sediment/basalt interface. Velocities ranging from 1.9 to $2.6 \mathrm{~km} / \mathrm{s}$ (seven measurements) have been computed for the upper layer from the profile $9 \mathrm{MCS}$ data. These velocities are slightly higher than those measured through sedimentary samples from the hole (Site 458 report, this volume). Velocities computed from MCS and refraction data (stations C20-177 and HIG 18-20; Table 1) for the material below this layer vary from 3.0 to slightly greater than $4.0 \mathrm{~km} / \mathrm{s}$. These velocities agree well with velocities measured through the basalt samples from the site. The discontinuous deep reflector at approximately 6.5 seconds at the western end of the profile may correspond to the $5.1-\mathrm{km} / \mathrm{s}$ refractor recorded at station C20-177 or, more likely, the $6.1-6.2-\mathrm{km} / \mathrm{s}$ refractor recorded on C20-177, HIG 18, HIG 19, and HIG 20 (Table 1).

\section{SITE 459}

This site is located in the Mariana fore-arc near the trench-slope break, approximately $50 \mathrm{~km}$ west of the Mariana Trench axis. A section of 559 meters of sediment was penetrated above an igneous basement (Site 459 report, this volume). The upper 64.5 meters of sediment comprises Pliocene-Pleistocene siliceous and calcareous ooze and mud with ash layers, while the following 475 meters of section is composed of mid-Miocene to upper Oligocene slumped turbidites. The bottom 19.5 meters of sediment is claystone with some chert; the oldest sediment is middle Eocene. The igneous section is composed of 132.5 meters of vesicular clinopyroxene plagioclase basalts. Profile 10 (Fig. 8a and b) passes approximately $1 \mathrm{~km}$ south of Site 459 . An upper, poorly stratified unit, $0.4-0.6$ seconds thick, is apparent on most of the profile and may correspond to the slumped turbidites recovered from the hole, at least in the regions immediately around the site. A lack of coherent, bedded reflectors would be expected in a sequence of chaotic, slumped and faulted sediments. It is difficult to determine the lateral extent of the slumped materials re- 

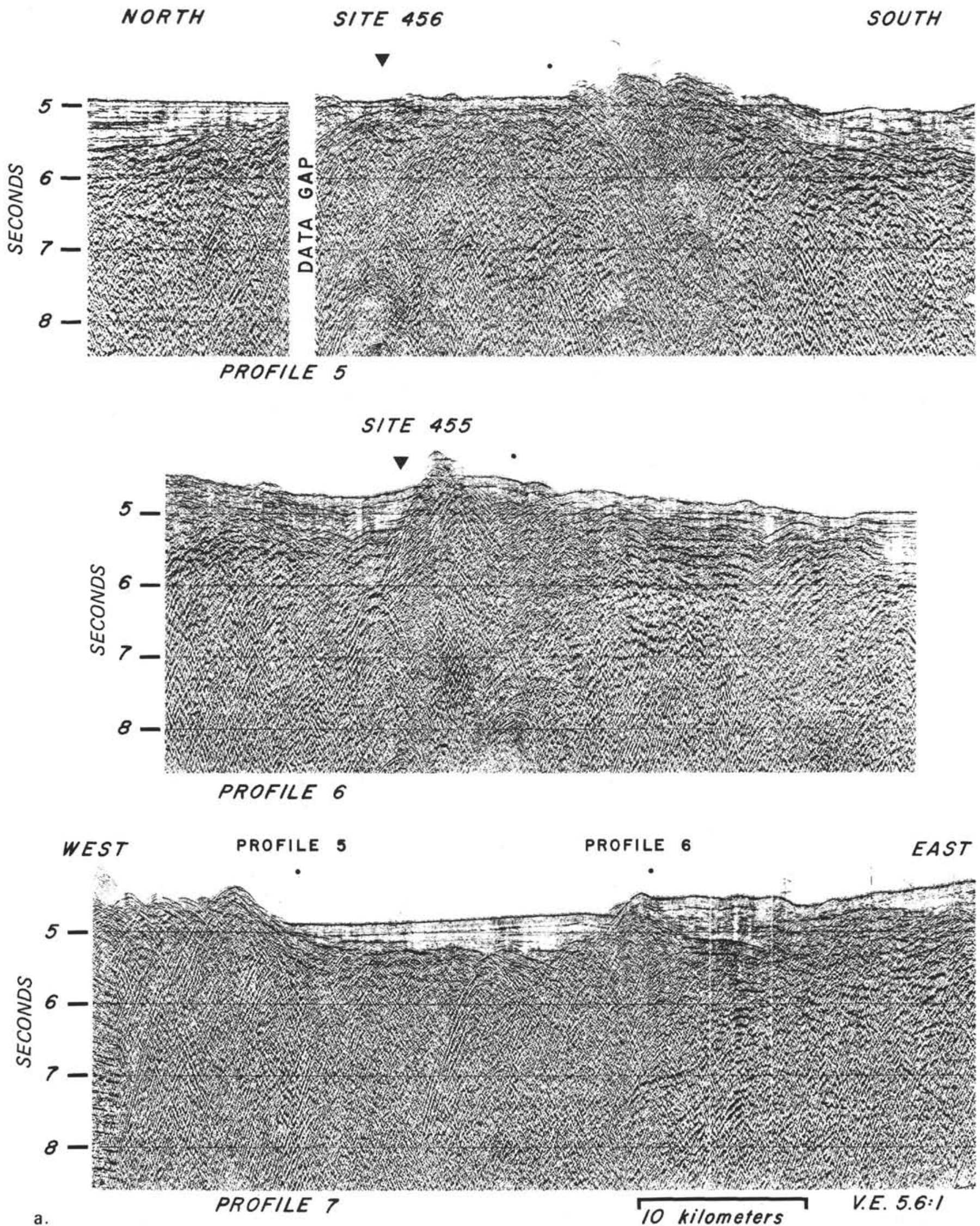

Figure 5A. MCS profiles 5-7. 

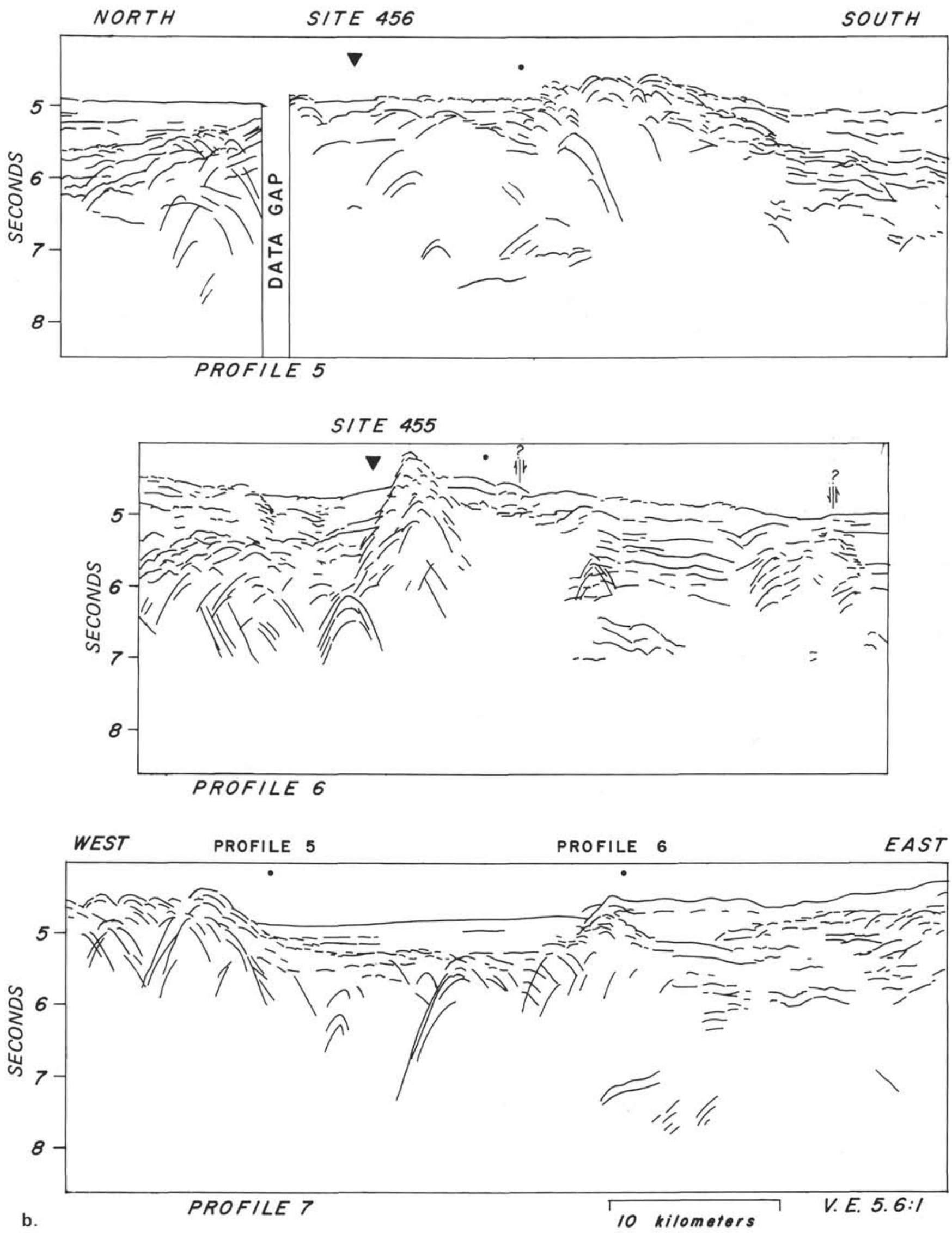

Figure 5B. Line drawings of MCS profiles 5-7. 


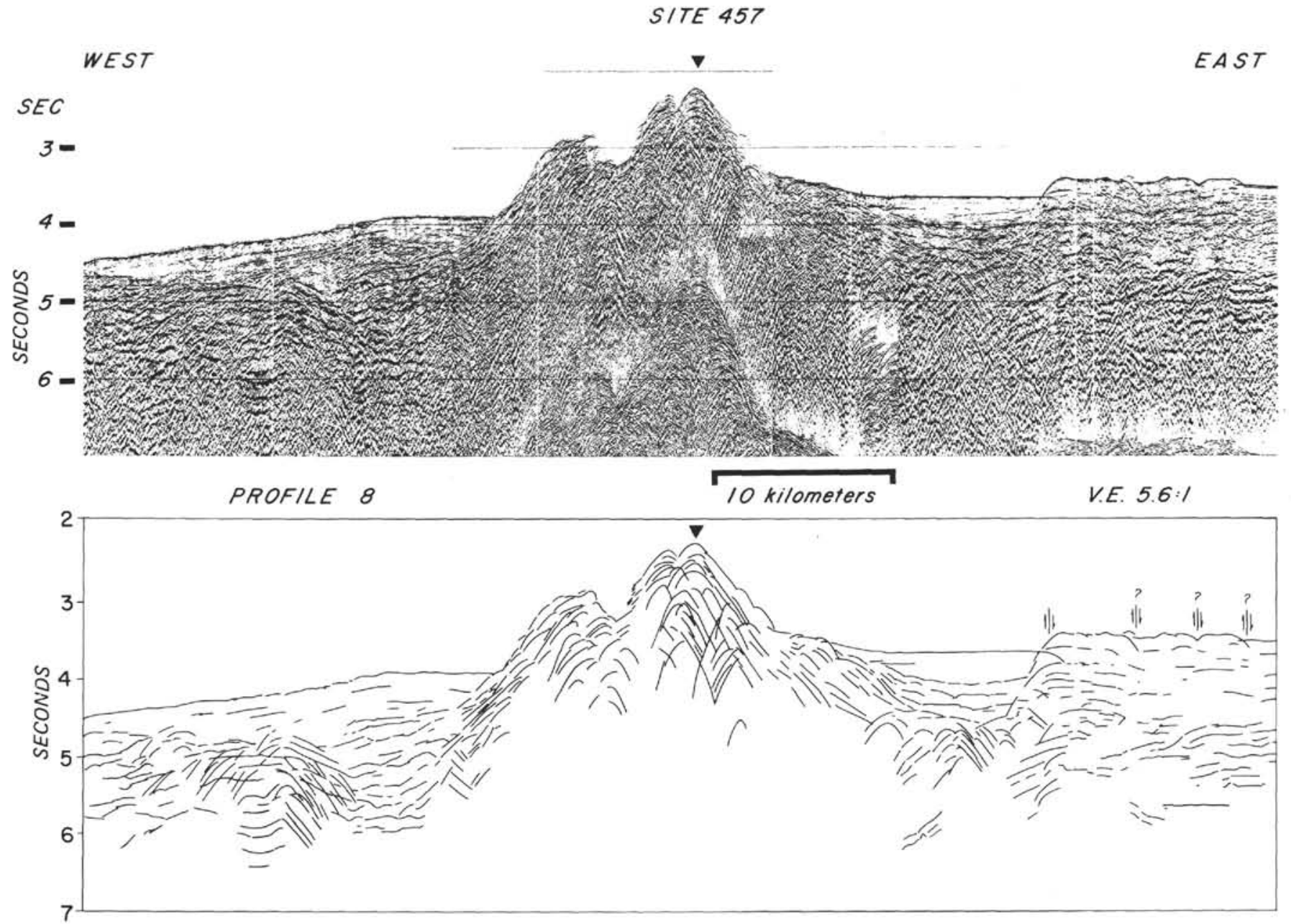

Figure 6. MCS profile 8 record section and line drawing.

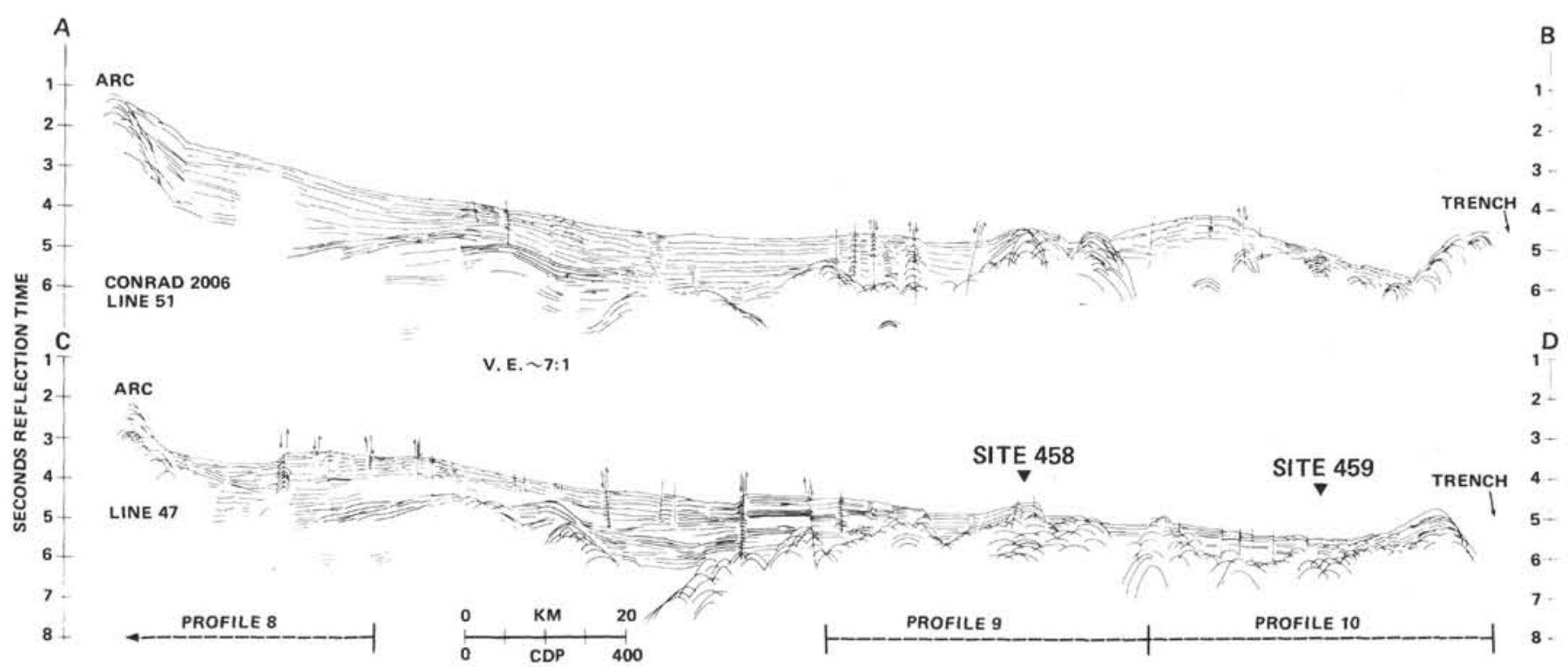

Figure 7. Line drawings from Mrozowski and Hayes (in press) of the two R/V Conrad MCS crossings of the Mariana fore-arc. Locations of lines shown in Figure 1; the positions of MCS profiles 8-10 and Sites 458 and 459 are indicated. Note the large number of normal faults which cut the flat lying sediments (also see Figs. 6, 8a, and $8 \mathrm{~b}$ ) and the eastward shoaling basement (Line 47). 
covered at Site 459. Away from the site, particularly to the west, the upper unit recorded on profile 10 may be composed of ooze and chalk beds, similar to those recovered at Site 458 (profiles 9 and 10 abut). Interval velocities of less than $2 \mathrm{~km} / \mathrm{s}$ have been determined for the upper unit near Site 459 from MCS data, but these are poorly constrained. The base of this unit corresponds to the top of the igneous rocks recovered from the hole. A refraction velocity of $4.14 \mathrm{~km} / \mathrm{s}$ has been recorded from this horizon (HIG 20; Table 1). The nature of the deep reflectors (7.0-8.0 s) east of the site is unclear.

\section{SITES 460 AND 461}

These sites are located on the inner wall of the Mariana Trench. Two holes were drilled at each site.

A short section $(19 \mathrm{~m})$ of Pleistocene diatom ooze and siliceous mud was recovered from the top of Hole 460. A section of 47.5 meters of crystal mud and Oligocene through Eocene calcareous and vitric mud with pebbly layers was penetrated below these sediments (Site 460 report, this volume). At Hole 460A, a Pleistocene diatom ooze and mud section $(17.5 \mathrm{~m})$ was recovered over a reworked section of Cretaceous and Cenozoic sediments. Ten meters of upper Oligocene to lower Miocene conglomerate with basalt fragments was recovered from the bottom of the hole. Holes 461 and $461 \mathrm{~A}$ were drilled downslope from Site 460 on a small bathymetric high, where it was hoped a presumed lack of coarse sediments would make drilling easier (Site 461 report, this volume). The materials recovered at Holes 461 and 461A are similar and are composed of an upper unit of siliceous ooze, a middle unit of clay and mud with pebbles, and a lower sedimentary-igneous-metamorphic conglomerate unit. The shipboard scientists speculate that the high on which Site 461 is located may be a slump block (Site 461 report, this volume). Penetration was 20.5 meters at Hole 461 and 15.5 meters at Hole 461A.

Profiles 11, 12, and 13 (Fig. 9a and b) pass near Sites 460 and 461. Profile 11 trends north-northeast and runs along the inner wall of the Mariana Trench. Reflections from the upper 1 second or more of the records are generally chaotic (only a few coherent reflections can be recognized), but this is not unexpected since reworking of the inner wall materials by slumping or tectonic processes is indicated by the drilling results. The strong reflector observed 1.4 seconds below the sea floor at the projected position of Site 461 and traceable to the north and south at a similar depth may correspond to the top of the underthrust Pacific plate. Interval velocities derived from MCS data across the inner wall are poorly constrained and variable, and their relationship to the actual in situ velocities is unclear.

Profile 12 is oriented east-west (perpendicular to the trend of the trench axis) and is approximately $23 \mathrm{~km}$ north of Site 460 and $12 \mathrm{~km}$ north of Site 461 . The upper surface of the Pacific plate can be traced from the eastern end of the profile westward, past the trench axis, to a point some $8 \mathrm{~km}$ west of the projected position of Site 461 where it is recognizable as a group of reflectors at approximately 10 seconds below the sea surface. The position of this group of reflectors above the trench axis is an artifact of the time section display of the profile: when the reflectors are restored to their correct positions in depth, the Pacific plate is seen to be dipping westward beneath the inner wall of the trench.

Profile 13, also oriented east-west, is located $1 \mathrm{~km}$ south of Site 460 and $12 \mathrm{~km}$ south of Site 461 . The top of the Pacific plate dips to the west and can easily be traced beneath the lower portion of the inner wall. Near the foot of the inner wall (below $10.5 \mathrm{~s}$ ), a small wedge of material is seen to pinch out to the west against the top of the downgoing Pacific plate. The terraces on the inner wall of the trench on profiles 12 and 13 may represent the sea floor expression of faults framing additional wedges of material. Although drilling at Sites 460 and 461 indicates that a large subduction complex is lacking at the Mariana Trench, these profiles suggest that a small one may be present.

\section{ACKNOWLEDGMENTS}

We would like to thank Richard Jarrard and Garry Karner for their critical reviews of this manuscript, and Hester Haring Cason and David Johnson for their technical assistance in its preparation. The processing of the MCS data was carried out at Lamont-Doherty under the direction of Paul Stoffa. Support for their collection, processing, and analysis was provided by National Science Foundation grants UC/NSF C482-2 and OCE 76-23382.

\section{REFERENCES}

Ewing, J., Ewing, M., Aitken, T., et al., 1968. North Pacific sediment layers measured by seismic profiling. In Knopoff, L., Drake, C. L., and Hart, P. J. (Eds.), The Crust and Upper Mantle of the Pacific Area: Washington (American Geophysical Union), pp. 147-153.

Hayes, D. E., Houtz, R. E., Jarrard, R. D., et al., 1978. Crustal structure. In Hayes, E. D. (Ed.), A Geophysical Atlas of the East and Southeast Asian Seas, Map and Chart Series MC-25: Boulder (Geological Society of America).

Heezen, B. C., MacGregor, I. D., et al., 1973. Init. Repts. DSDP, 20: Washington (U.S. Govt. Printing Office).

Hegarty, K. A., Jarrard, R. D., and Anderson, R. N., 1980. Detailed multichannel analysis of the structure of a mound-type hydrothermal area in the Mariana Trough (abstract). EOS Trans., 61:364

Houtz, R. E., and Ludwig, W. J., 1979. Distribution of reverberant subbottom layers in the southwest Pacific Basin. J. Geophys. Res., 84:3497-3504.

Kan, T. K., Mrozowski, C. L., Taylor, B., et al., 1978. Multichannel seismic observations of the Mariana arc-trench system. EOS Trans., 59:321. (Abstract)

Kroenke, L. Scott, R. B., et al., 1980. Init. Repts. DSDP, 59: Washington (U.S. Govt. Printing Office).

Langseth, M. G., and Mrozowski, C. L., 1980. Geophysical surveys for Leg 59 sites. In Kroenke, L., Scott, R. B., et al., Init. Repts. DSDP, 59: Washington (U.S. Govt. Printing Office).

LaTraille, S. L., and Hussong, D. M., in press. Crustal structure across the Mariana island arc system. In Hayes, D. E. (Ed.), The Tectonic and Geologic Evolution of Southeast Asian Seas and Islands: Washington (American Geophysical Union).

Mrozowski, C. L., and Hayes, D. E., in press. A seismic reflection study of faulting in the Mariana Forearc. In Hayes, D. E. (Ed.), The Tectonic and Geologic Evolution of Southeast Asian Seas and Islands: Washington (American Geophysical Union). 

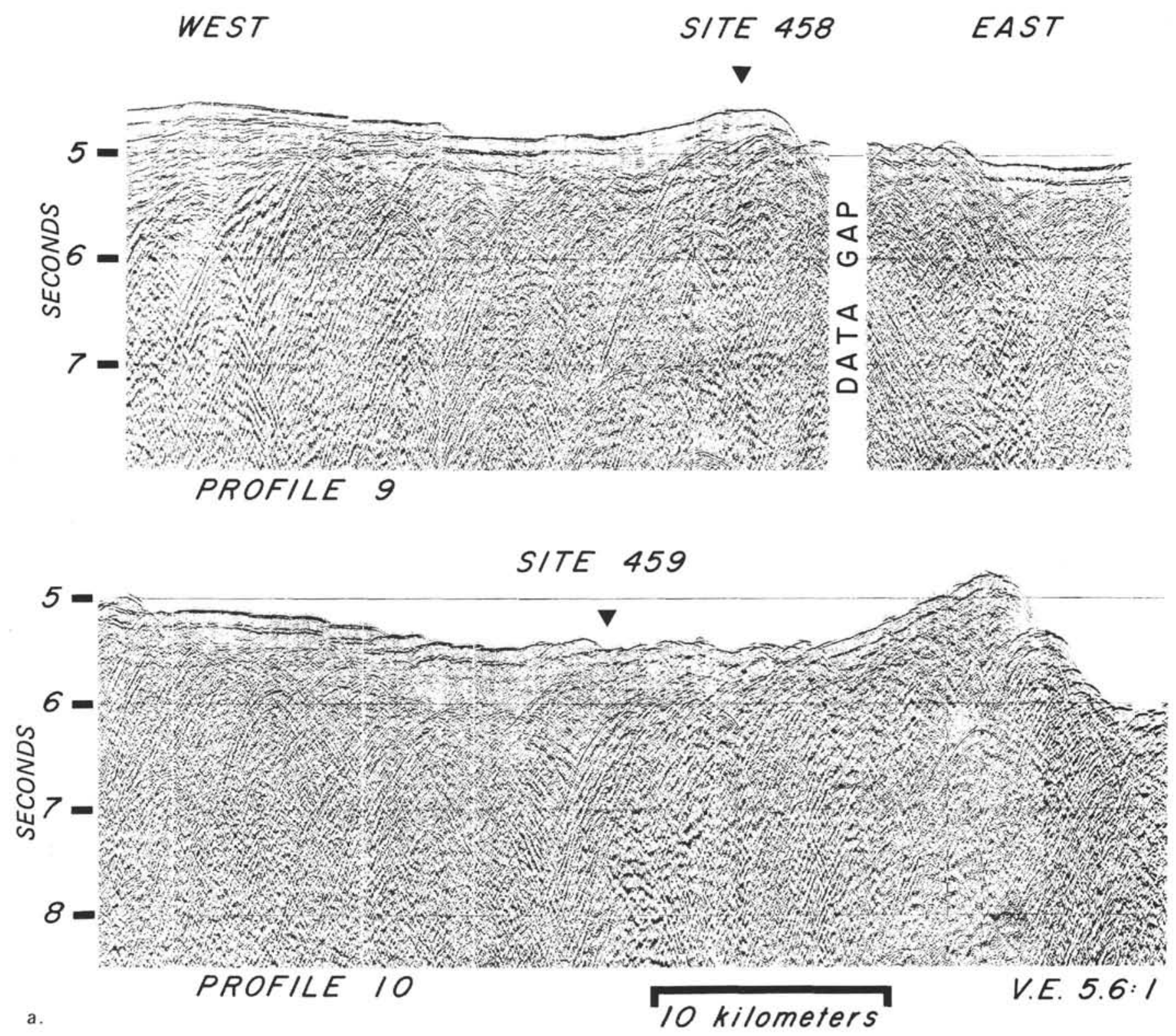

Figure 8A. MCS profiles 9 and 10 . 



Figure 8B. Line drawings of MCS profiles 9 and 10 . 


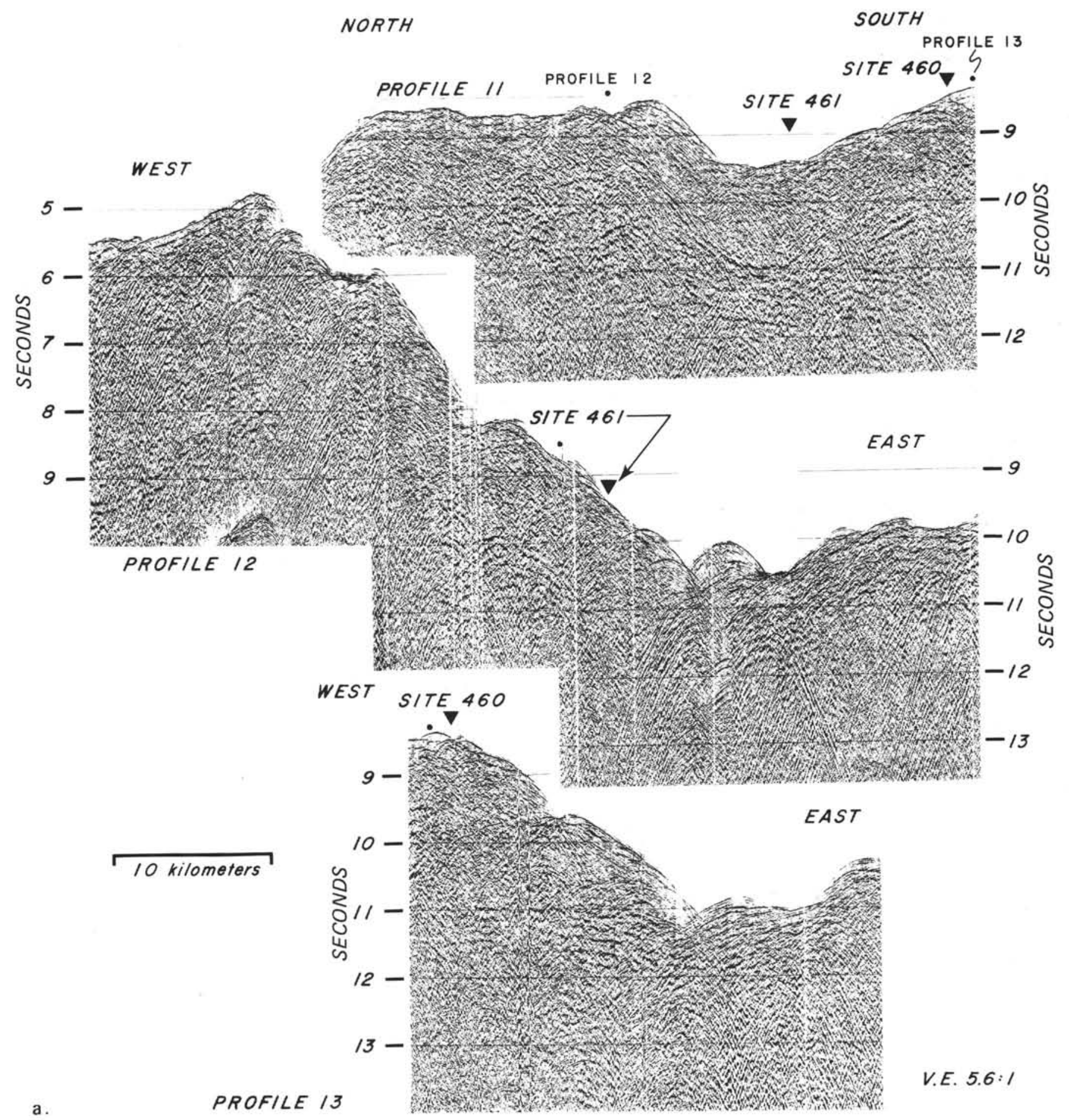

Figure 9A. MCS profiles 11-13. 


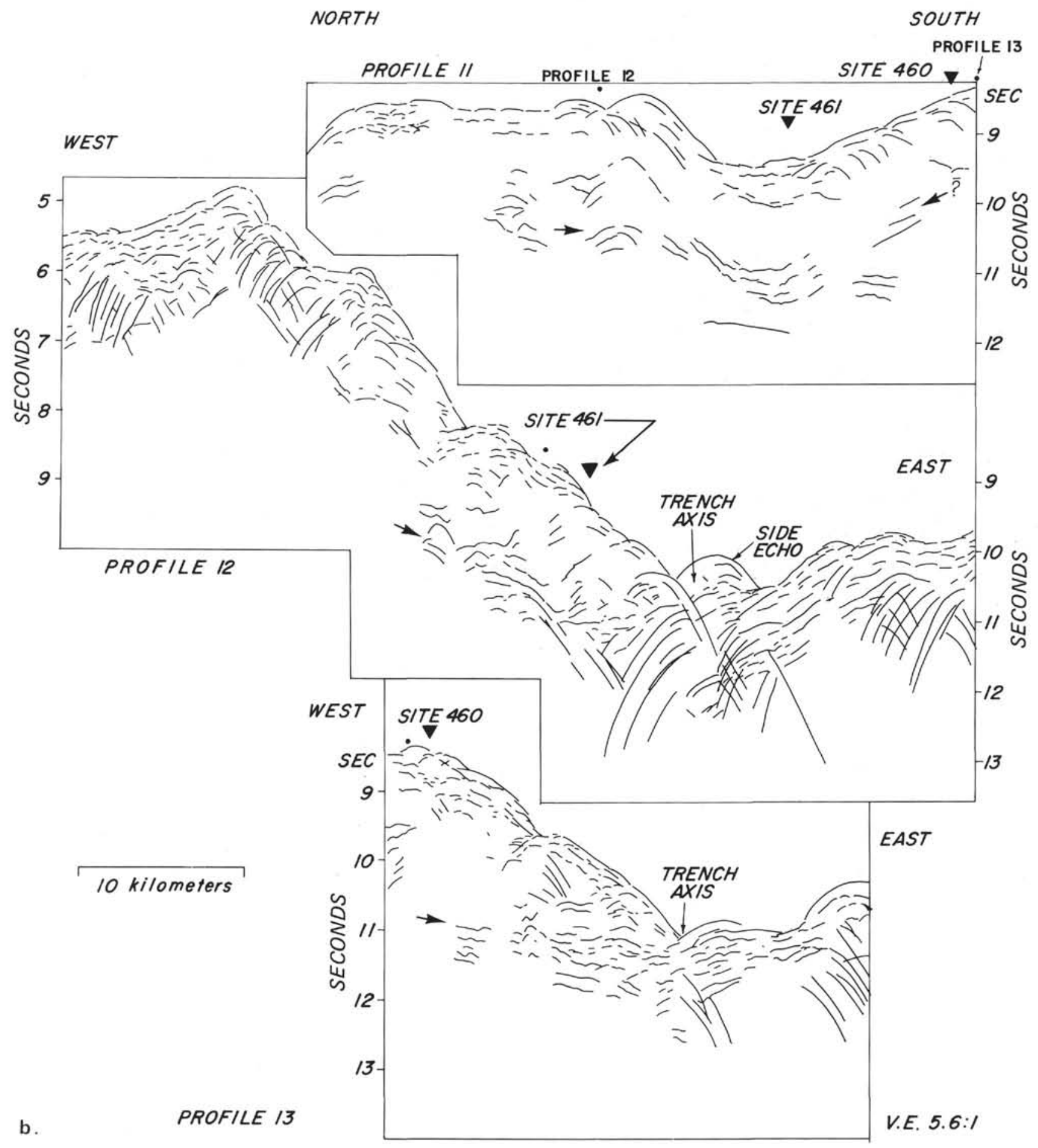

Figure 9B. Line drawings of MCS profiles 11-13. Heavy arrows indicate top of the Pacific plate. 